\title{
Technological Pedagogical Content Knowledge: Implementation of a Didactic Proposal for Preservice History Teachers
}

\author{
Carlos D. Ciriza-Mendivilit ${ }^{*}$, Ana Mendioroz Lacambra ${ }^{1}$ and \\ José M. Hernández de la $\mathrm{Cruz}^{2}$
}

${ }^{1}$ Human Science and Education, Public University of Navarra, Pamplona, Spain, ${ }^{2}$ Specific Didactics, University of Zaragoza, Zaragoza, Spain

Information and communication technologies (ICTs) now form part of virtually all aspects of our daily lives, including education. However, teacher training in digital competence has been pushed into the background, especially in social sciences and in history instruction, in which digitalization and the use of ICTs is an opportunity for improvement and educational innovation. Consequently, proposals integrating the various types of knowledge into the training of history teachers are still rare and scarce. To solve this problem, this study presents a mixed quantitative and qualitative analysis using a pre-

OPEN ACCESS

Edited by: Álvaro Chaparro-Sainz, University of Almería, Spain

Reviewed by: Sebastián Molina-Puche, University of Murcia, Spain Emilio José Delgado-Algarra, University of Huelva, Spain

*Correspondence: Carlos D. Ciriza-Mendívil carlos.ciriza@unavarra.es

Specialty section: This article was submitted to

Teacher Education, a section of the journal

Frontiers in Education

Received: 11 January 2022 Accepted: 27 January 2022 Published: 24 February 2022

Citation: Ciriza-Mendívil CD, Lacambra AM and Hernández de la Cruz JM (2022)

Technological Pedagogical Content Knowledge: Implementation of a Didactic Proposal for Preservice History Teachers.

Front. Educ. 7:852801. doi: 10.3389/feduc.2022.852801 and posttest questionnaire with a sample of 235 students of the primary education degree at the Public University of Navarre who took part in an innovative didactic proposal that was implemented using the technological pedagogical content knowledge (TPACK) model based on digitized primary sources in three resources: PARES (Spanish Archive Portal), EUROPEANA, and BNE (National Library of Spain). The primary aim of this study was for preservice teachers to develop digital competence in teaching social sciences by integrating the technological, pedagogical and content knowledge types using the TPACK model. There were three specific objectives. The first was analyzing the digital knowledge of students following a primary education degree concerning the use of ICTs in history instruction. The second was implementing a didactic proposal in the teaching social sciences course based on the TPACK model by integrating ICTs and history instruction using Spanish and European digitized primary historical sources. Finally, the third was evaluating the impact of this didactic proposal on developing the knowledge types linked to the TPACK model, especially content knowledge (CK) and its technological content knowledge (TCK) and pedagogical content knowledge (PCK) combinations.

Keywords: TPACK, historical thinking, preservice teachers, ICTs - information and communication technologies, history instruction

\section{INTRODUCTION}

The development of information and communication technologies (ICTs) has been one of the most significant constituents of change in recent decades (Mishra and Koehler, 2006). Besides altering social relationships, communication, and information, their impact has transformed society and posed a major challenge in education (Jiménez Sabino and Cabero Almenara, 2021). 
As a result, it is becoming increasingly obvious that the individuals forming our current society and who will shape the future one will need to develop digital competence (DC) to a high level in order to function properly (Cabero and Palacios, 2020; Hidalgo Cajo and Gisbert Cervera, 2020; MiguelRevilla et al., 2020). This need has been even more evident, if possible, in the past 2 years when the exceptional circumstances caused by COVID-19 have led to transformation toward an unprecedented digital and virtual education at all educational levels. Simultaneously, this accelerated change has highlighted the need to begin promoting the development of DC in classrooms based on improved pedagogy and the significant development of digital competence of educators (DCE) (CaberoAlmenara and Llorente-Cejudo, 2020; Romero Tena et al., 2021).

This position, which has become increasingly widespread among social sectors (García-Valcárcel and Martín del Pozo, 2016), has also been echoed at all institutional levels in recent years: in the creation of national and international standards that include improvement and implementation proposals for DC and DCE (International Society for Technology in Education [ISTE], 2008; UNESCO (2008, 2016); Ministry of Education Malaysia, 2012; DIGCOM; DigComEdu), and in curricular and legislative development for use in classrooms. In this regard, in Europe, DC has been included among the key competences for learning (Commission of the European Communities, 2006). Consequently, DC has to be developed to improve educational practice (Redecker and Punie, 2017). In Spain, this competence has been included in the latest educational legislations (LOE, LOMCE, and LOMLOE), and also in the curricular frameworks established by regulations to govern the initial training of teachers studying primary and preschool education degrees (Order of the Ministry of Education, Science, and Innovation 3857/2007 of 27 December, Objective 11).

However, the education system still faces numerous challenges and difficulties where DC is concerned, and the causes of the delay in implementing it in the various learning processes are diverse (Mishra and Koehler, 2006). On balance, the norm in both classrooms and teacher training has been to focus didactic and pedagogical proposals concerning DC on using new equipment and resources (Hargrave and Hsu, 2000; Graham et al., 2004, 2009; Mishra and Koehler, 2006; Ortega Sánchez, 2015), reproducing explanatory and traditional methodologies that have not enabled the breadth of changes needed in education (Cabero and Marín, 2014; Cejas León et al., 2016; Gómez Trigueros, 2017).

Given this situation, we should remember that new educational contexts not only require more technological resources but also a real change process that affects DC, DCE, and, therefore, educational practice and roles in the classroom. The development of ICTs does not merely consist of applying new resources but also, and especially, of promoting their implementation as an integrated pedagogical tool in the educational development of students (Tirado and Aguaded, 2014; González et al., 2018; Ramma et al., 2018). Furthermore, concerning educational practice and roles in the classroom, the use of ICTs in teaching-learning processes cannot occur independently as it must be linked to methodological, pedagogical, and content innovation processes in which teachers' and students' roles overcome traditional approaches (Rivero and Mur, 2015).

For this to occur, initial teacher training should be presented as a space for preferential action and, simultaneously, as a didactically and pedagogically complex field. On the one hand, courses linked to ICTs in teacher training are scarce, especially in the specific area of social sciences (Ortega Sánchez, 2015; García-Valcárcel and Martín del Pozo, 2016). This lack of training coupled with teachers' lack of knowledge in how to use ICTs in the classroom means that the dissemination media for history instruction technologies are often personal blogs and colleagues' recommendations, as highlighted by Flores and Rivero (2014). On the other hand, even in cases in which courses and training models have been rolled out (Price and Kirkwood, 2014; Voithfer et al., 2019; Koh, 2020; Ortiz-Colón et al., 2020), lack of knowledge and interest in technologies persists among most teaching personnel of the various disciplines and also in history instruction.

Consequently, the starting point of this study is this complex issue (see, for example, Colomer Rubio et al., 2018; Hidalgo Cajo and Gisbert Cervera, 2020; Ortiz-Colón et al., 2020), in which a lack of interest and pedagogical training is combined with an obvious need (Sharp, 2014) to develop DCE, in this particular case with the added difficulty of linking it to social sciences and the development of historical thinking in the classroom, as some studies have done (VanSledright, 2013; Colomer Rubio et al., 2018; Ortega-Sánchez and Gómez Trigueros, 2020; Rinder, 2020).

\section{BACKGROUND: THE TPACK MODEL}

The scientific literature on DCE and teaching training has a relatively long history that began at the end of the twentieth century. Initially, ICTs in the classroom were analyzed and developed on the fringes of the pedagogical or content dynamics and processes implemented at various educational levels (Hargrave and Hsu, 2000; Graham et al., 2004). The aim at that time was to present various media and resources to develop what was considered technological knowledge, which differed from other knowledge imparted in teaching and learning processes. However, in-service and preservice teachers that had begun to implement technological models and proposals soon observed problems with this separation. Consequently, they advocated that technologies had to be linked to the other factors involved in the educational process (Gómez Trigueros, 2016) and by the start of the twenty-first century, technology integration had become the objective to achieve (Graham et al., 2009).

Several educational proposals and training models soon appeared to respond to this demand, seeking to integrate technological knowledge (TK) with the other aspects of the educational process (Moersch, 2002; Lee et al., 2007). It is in this context that Mishra and Koehler (2006) developed the technological pedagogical content knowledge (TPACK) model. This proposal was based on the educational knowledge theories put forward by Shulman $(1986,1987)$, who advocated the existence and link in the classroom of two types of knowledge 
that teachers should impart for their teaching to prove successful: pedagogical knowledge (PK) and content knowledge (CK). This model, known as pedagogical content knowledge (PCK), supported the idea that the knowledge types needed to be integrated in the classroom and that none was independent. Despite the criticism leveled at PCK (Cochran et al., 1993; Van Driel et al., 1998), the model has remained current over the years. Consequently, with technological innovation as an objective, and using the bases of PCK, Mishra and Koehler (2006) added a new type of knowledge, TK, and developed their new model, originally known as TPCK and later as TPACK (Jang and Chen, 2010).

The TPACK model kept the main principle of the theories of Shulman $(1986,1987)$, namely the integration of the knowledge types; therefore, it was not a simple TK add-on. According to Mishra and Koehler (2006), it is a technological integration model of ICTs in teaching and learning. For this to occur properly and successfully, the three main types of knowledge-TK, PK, and $\mathrm{CK}$ - should not be implemented independently; instead, the focus should be especially on knowledge developed from the three interacting with each other, in other words, technological pedagogical knowledge (TPK), technological content knowledge (TCK), and pedagogical content knowledge (PCK), whose intersection finally gave rise to the TPACK (see Figure 1).

Although the TPACK model currently has the essential structure developed by Mishra and Koehler (2006) and Koehler and Mishra (2008), it has been adapted several times in recent years (Angeli and Valanides, 2009; Jang and Chen, 2010; Van Vaerenewyck et al., 2017). These adaptations have been especially important for contextual knowledge (XK) as another element in teaching development (Porras-Hernández and Salinas-Amescua, 2013; Rosenberg and Koehler, 2015; Phillips et al., 2016; Swallow and Olofson, 2017), which was included in the last revision of the TPACK by Mishra (2019). The relative stability of the main bases of the model has coexisted with extensive scientific literature outlining its limitations and issues (Mishra, 2019).

On the one hand, some analyses have considered TPACK as an ill-advised proposal that does not apply in some educational contexts (Abbitt, 2011). These analyses emphasize some of the aspects they consider problematic in the model, for example, the excessive pursuit of technological sophistication in some studies when applying TPACK (Roussinos and Jimoyiannis, 2019), the complexity of practically applying the model as it is divided into many types of knowledge (Angeli and Valanides, 2009) and, consequently, the difficulty in implementing an instrument to evaluate the acquisition of different types of knowledge (Phillips, 2016; Özgen and Serkan, 2020).

On the other, some studies have tried to improve and expand the model in different ways, even though they have detected problems with Mishra and Koehler's proposal in several contexts. For example, the technology, pedagogy, content and spaces (TPeCS) knowledge model (Kali et al., 2019), the study designed to reconceptualize the model, including a scope and apparatus of literary criticism by Watulak and Kinzer (2013), and, especially, other analyses focused on applying the TPACK model with the aim of developing e-teaching resources and specific applications (Ortega-Sánchez and Gómez Trigueros, 2019; Miguel-Revilla et al., 2020).

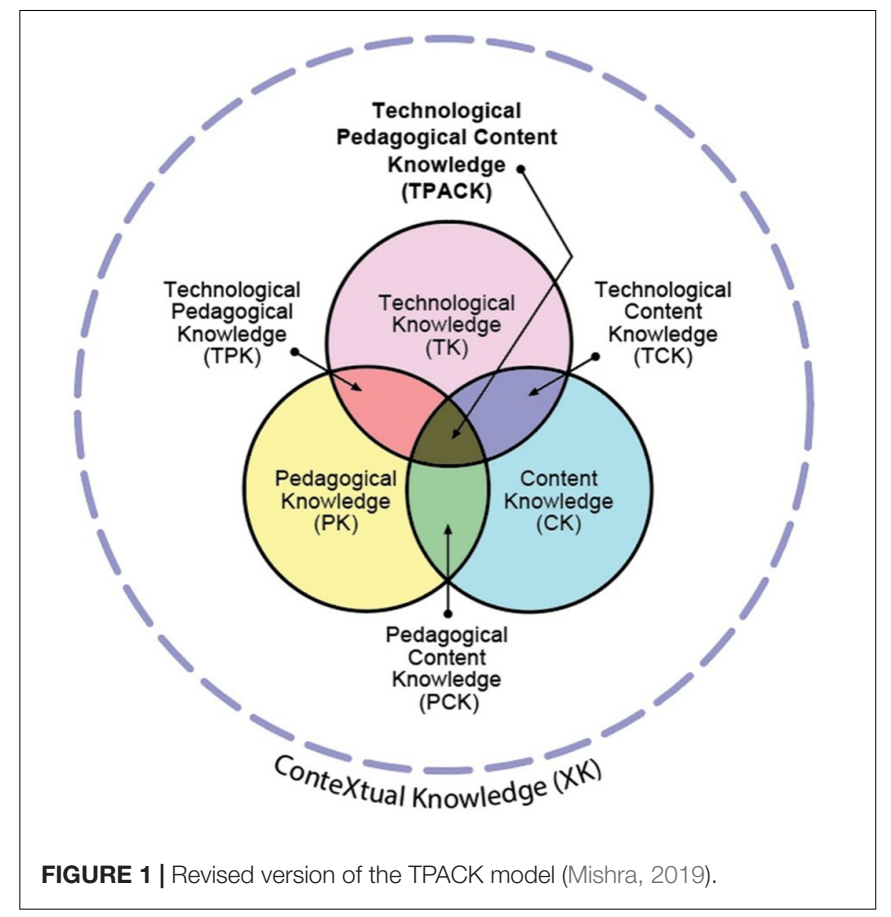

Nevertheless, although the TPACK model has been criticized and modified, many studies have defended its validity for integrating ICTs into the classroom in all educational spheres (Cabero, 2014; Barac et al., 2017; Hsu and Lin, 2020), but especially referring to teacher training in several areas and disciplines (Redmond and Peled, 2018; Agustín et al., 2019; Atun and Usta, 2019; Koh, 2019; Ladrón et al., 2019; Valtonen et al., 2019; Kaplon-Schilis and Lyublinskaya, 2020; Kong and Lai, 2021). However, as mentioned above, the TPACK model is still a novel and emerging practice in the teaching of social sciences (Willermark, 2018). In any event, in the past decade, the TPACK has been applied in aspects such as the creation and use of specific ICT resources for the classroom (Lee and Tsai, 2010); the perception and self-perception of ICTs and their integration by in-service teachers at several levels (Graham et al., 2009; Cózar et al., 2015; Van Vaerenewyck et al., 2017; Jiménez Sabino and Cabero Almenara, 2021); curricular analysis (Ortega Sánchez, 2015); and, essentially, initial teacher training in social sciences, which includes, among other elements, a direct or indirect link with several aspects of historical thinking in the teaching-learning process (Gómez Trigueros, 2016; Colomer Rubio et al., 2018; Miguel-Revilla et al., 2020; Ortega-Sánchez and Gómez Trigueros, 2020; Rinder, 2020).

\section{METHOD}

This research starts with the hypothesis that, although preservice teachers are "digital natives," they are not "digital experts" (Miguel-Revilla et al., 2020; Romero Tena et al., 2021). Therefore, despite knowing and being familiar with ICTs, they are not capable of integrating technologies into their future teaching work and far less capable of applying them at a specific content and pedagogical level. 
The main objective of this study was for students of the primary education degree to develop DCE in the field of social sciences by integrating content, pedagogical, and technological knowledge in cooperative settings using the TPACK model (Mishra and Koehler, 2006).

The following are the specific objectives.

First objective (SO1): analyzing the digital knowledge of students following a primary education degree concerning the use of ICTs in history instruction.

Second objective (SO2): implementing an educational proposal in the teaching social sciences course based on the TPACK model by integrating ICTs and history instruction using Spanish and European digitized historical sources.

Third objective (SO3): evaluating the impact of this didactic proposal on the development of the knowledge types linked to the TPACK model, especially CK and its TCK and PCK combinations.

The research we present in this study is descriptive and experiential. Given that mediation and evaluation of the TPACK model and its knowledge types have been seen as one of the difficulties in implementing it in the classroom, this study addresses that problem in the way other studies have (Cózar et al., 2015; Gómez Trigueros, 2016) by developing a mixed research model combining quantitative and qualitative analysis factors (Kaplowitz et al., 2004). For that purpose, this study is based on two questionnaires before and after implementing a didactic experience using the teaching-learning TPACK model and three ICT resources linked to history and the digitalization of primary sources (BNE, PARES, and EUROPEANA) in the classroom.

An experimental design was used in both the quantitative and qualitative approaches using questionnaires created from instruments already developed for the TPACK model (Schmidt et al., 2009; Cabero et al., 2015; Ortega-Sánchez and Gómez Trigueros, 2019; Valtonen et al., 2019) and validated by experts from Nebrija University and the European University of Madrid for this specific proposal. The questionnaires contained a first general identification part and a second part that included closed, open, and Likert-type questions (Cejas León et al., 2016; Lopera Pérez et al., 2020), which corresponded to selfperception of the TPACK model knowledge types: PCK in questions aimed at applying several historical thinking aspects in the primary classroom (questions 1-7); TPK in questions focused on ICT knowledge and its application in the social sciences classroom in primary school (questions 8, 9, 10, and 11 ); and TCK in questions on integrating ICTs in the history classroom (questions 12 and 13). The quantitative analysis was performed using the RStudio program, and the qualitative analysis of the sections with open answers was based on reducing, categorizing, and coding data based on TPACK model information and KWIC and KWOC approaches using the Atlas.ti program.

The didactic proposal was completed over a total of four sessions lasting $2 \mathrm{~h}$ each. The aim was to understand the complex dynamics and interrelations between teaching, content, and technology in a specific context. Consequently, this study proposed to analyze the development of historical thinking among preservice teachers by means of collaborative work structured on problem-based learning enabling the impact and modifications caused by the TPACK model to be analyzed (Colomer Rubio et al., 2018). The goal was to create an active learning space for preservice teachers that would change the students' role through technologies and, in this case, enable collaborative e-activities to be implemented in the classroom (Baran and Uygun, 2016) based on the use and educational transposition of digitized primary historical sources (Britt and Aglinskas, 2002; Haydn, 2013; Rinder, 2020).

The didactic experience took place in the two groups of the teaching social sciences course in the second year of the primary education degree taught in Spanish (Group 1 and Group 2) and in a group in the teaching social sciences course in the second year of the international primary education degree taught in English (Group 81). Consequently, the sample used is non-probabilistic, convenience, or causal (Sabriego, 2012), in other words, based on how easy it was for the researchers in this study to access the subjects participating in it (Neuman, 2007; Wellington, 2015). Given that the course in which the proposal was implemented is compulsory, the sample did not include a control group; however, as it is formed by a total of 235 subjects (pretest $n=127$, posttest $n=108)$, it can be considered representative of the total population $(n=600)$ as it exceeds the minimum established for this type of studies with surveys in social sciences (Sevillano, 2002). Concerning the general characteristics of the sample, the mean age is 19.4 years and, although the range is 12 , the standard deviation is 1.59; therefore, the sample is relatively homogenous in this aspect. Concerning the analysis groups, their numbers vary; the largest is Group 1, followed by Group 81, and, finally, Group 2 (see Table 1).

\section{RESULTS}

The TPACK model is based on integrating the knowledge types (Koehler and Mishra, 2008) needed for successful teaching and appropriate DCE. Consequently, the results of this study are presented below on the basis of these knowledge types (CK, PK, and TK), and, especially, of their integration (PCK, TPK, and TCK).

The results were generally positive, especially concerning CK, and, particularly, PCK. Starting with question 1 (Table 2), the pretest and posttest results of the initial questions of this section are shown with Likert-type responses, specifying the mean (M), median (Median), interquartile range (IQR), and variance (VAR). For the quantitative analysis, the Likert-type responses"completely disagree" (1), "slightly disagree" (2) "neither agree

TABLE 1 | Sample by groups.

\begin{tabular}{lcc}
\hline & Pretest $\boldsymbol{N}$ & Posttest $\boldsymbol{N}$ \\
\hline Group 1 & 58 & 43 \\
Group 2 & 30 & 30 \\
Group 81 & 39 & 35
\end{tabular}


nor disagree" (3), "slightly agree" (4), and "completely agree" (5)-were numerically transform in the data (Table 2).

In the CK and PCK questions, shown in Table 2, we can observe that a large number of students showed a relatively positive perception with an upward trend in the posttest results that is, however, limited by the good initial results.

The most positive responses were provided for two issues: the first was the question on the importance of learning history (shown in the table as "PretestHistImp" and "PosttestHistImp"). Most of the sample was aware of the importance of history in both the pretest and posttest, and this was the most common response with a significantly reduced variance $(0.373$ in the pretest and 0.324 in the posttest). The second question with a highly positive response concerned the importance of the teachers and their explanations in history instruction ("Pretest Explain" and "Posttest Explain" with a mean response somewhere between "slightly agree" and "completely agree" and staying almost the same after implementing the proposal.

The results were positive, although slightly less than above, in four questions. The first concerned rote learning ("HistRoteLearn"), perceived as the most usual by students before the TPACK model proposal. In this case, a substantial improvement was observed in the posttest up to an intermediate level, although with a variance of 1.298 , a fact evidencing dispersion in the students' perception. The second concerned the different versions in the historical stories ("Versions"), with slightly improved results in the posttest, even though with a trend toward maintaining the results. The third was related to the development of empathy in history instruction ("Empathy"), which was not significantly modified from the proposal of the TPACK model implemented with digitized sources, although the students perceived its importance. Finally, the fourth was the question on the importance of using primary sources in the classroom ("Pretest Sources" and "Posttest Sources"), a central part of this study deserving special attention. The pretest and posttest results showed that preservice teachers have a generalized

TABLE 2 | Pretest/posttest comparison question 1.

\begin{tabular}{lcccc}
\hline & Mean & Median & IQR & Var \\
\hline PretestHistlmp & 4.567 & 5.000 & 1.000 & 0.373 \\
PosttestHistlmp & 4.542 & 5.000 & 1.000 & 0.324 \\
PretestHistRoteLearn & 3.810 & 4.000 & 2.000 & 1.083 \\
PosttestHistRoteLearn & 3.150 & 3.000 & 2.000 & 1.298 \\
Pretest sources & 3.881 & 4.000 & 1.000 & 0.842 \\
Posttest sources & 4.194 & 4.000 & 1.000 & 0.868 \\
Pretest versions & 4.173 & 4.000 & 1.000 & 0.842 \\
Posttest versions & 4.306 & 4.000 & 1.000 & 0.625 \\
Pretest opinions & 2.667 & 2.500 & 1.000 & 1.520 \\
Posttest opinions & 2.574 & 2.000 & 1.000 & 1.574 \\
Pretest explain & 4.619 & 5.000 & 1.000 & 0.382 \\
Posttest explain & 4.620 & 5.000 & 1.000 & 0.387 \\
Pretest empathy & 4.008 & 4.000 & 2.000 & 0.833 \\
Posttest empathy & 4.250 & 4.000 & 1.000 & 0.731 \\
Pretest knowledge & 2.551 & 2.000 & 1.000 & 1.059 \\
Posttest knowledge & 2.769 & 3.000 & 1.000 & 0.852 \\
& & & &
\end{tabular}

positive perception, and even a slight improvement, after the proposal, but with a relatively important variance $(0.842$ in the pretest and 0.868 in the posttest). The latter prevents us from advocating a direct and clear link between working with sources and improvement as perceived by students. Although this improvement occurs, the wide variance evidences discrepancies in perception by subjects in the sample.

Lastly, the most negative results in the responses in Table 2 were observed in two questions; however, the analysis of both differs. The first is the question linked to the use of diverse opinions and historical divergent approaches in teaching ("Pretest Opinions" and "Posttest Opinions"). In this case, the results showed the students' negative perception of this type of practice in teaching-learning processes. In any event, the variance in the responses is the largest of the entire sample ( 1.520 in the pretest, 1.584 in the posttest), showing the dispersion and, therefore, the broad difference in opinion in this regard. The second is the question with the clearest negative response, focused on CK and PCK, linked to the negative self-perception that preservice teachers have of their content and pedagogical knowledge for history instruction. Despite having the worst result in the pretest, this aspect, already observed in other studies (Colomer Rubio et al., 2018), exhibited one of the most substantial improvements linked to our didactic proposal between the pretest and the posttest. Consequently, there was an increase in the mean (2.551 in the pretest and 2.769 in the posttest), and especially in the median, which changed from "slightly disagree" (2.000) to "neither agree nor disagree" (3.000), at the same time as the variance decreased (1.059 in the pretest to 0.852 in the posttest).

The following tables continue with the questions focused on CK and PCK, namely, question 2 (Table 3), question 4 (Table 4), and question 6 (Table 5). They were questions with closed nominal "Yes/No" qualitative responses that were transformed into " $1 / 2$ " for the numerical analysis. These questions were complemented by the linked open-response questions, namely, question 3 to question 2, question 5 to question 4 , and question 7 to question 6 (see Tables 3-5).

A clearly positive trend can be observed in all the questions based on the implemented TPACK model proposal. This can be interpreted as a significant increase in the students' knowledge, in this case, CK and PCK. Concerning historical thinking (question 2 ), this improvement is especially significant, increasing from a total of 28 students with knowledge of it in the pretest $(22 \%)$ to 88 in the posttest $(81.4 \%)$. The open responses to question 3 allow us to qualify the results of question 2 (Table 3 ).

TABLE 3 | Pretest/posttest results question 2.

\begin{tabular}{lccc}
\hline \multicolumn{1}{c}{ Pretest historical thinking } & \multicolumn{2}{c}{ Historical thinking posttest } \\
\hline Mean & 1.779527559 & Mean & 1.18691589 \\
Typical error & 0.036932408 & Typical error & 0.037865 \\
Median & 2 & Median & 1 \\
Mode & 2 & Mode & 1 \\
Standard deviation & 0.416207096 & Standard deviation & 0.39167856
\end{tabular}


Consequently, most of the 28 students who say they know what historical thinking is in question 2 linked it in the responses to question 3 with the concepts of "historical knowledge" and "learning about history": "it is knowledge we have acquired through historical learning" or "having a point of view that shows you have knowledge of the past." However, none of the responses to question 3 linked historical thinking with the idea of "historical competence." In a few cases historical thinking aspects were mentioned, such as historical perspective: "it is thinking in the same way as people did during the era we are studying." In any event, the posttest results show a clear improvement with far more elaborate responses in which the elements and concepts mentioned include "interpreting historical processes," the "historical narrative," "historical reflection," and, especially, understanding historical thinking as the capacity to think and imitate a historian's work by using historical sources, for example in responses such as "it is thinking like historians" or "it is students' ability to think as a historian would, to understand how history is made."

The responses to question 4 (Table 4) on knowledge of the historical method and its qualitative details in question 5 show a similar trend to the previous questions. Furthermore, in the

TABLE 4 | Pretest/posttest results question 4.

\begin{tabular}{lccc}
\hline \multicolumn{1}{c}{ Pretest historical method } & \multicolumn{2}{c}{ Posttest historical method } \\
\hline Mean & 1.71653543 & Mean & 1.26851852 \\
Typical error & 0.04014976 & Typical error & 0.04284468 \\
Median & 2 & Median & 1 \\
Mode & 2 & Mode & 1 \\
Standard deviation & 0.45246482 & Standard deviation & 0.44525497
\end{tabular}

TABLE 5 | Pretest/posttest results question 6.

\begin{tabular}{lccc}
\hline \multicolumn{1}{c}{ Pretest historical sources } & \multicolumn{2}{c}{ Posttest historical sources } \\
\hline Mean & 1.433070866 & Mean & 1.009259259 \\
Typical error & 0.04414267 & Typical error & 0.009259259 \\
Median & 1 & Median & 1 \\
Mode & 1 & Mode & 1 \\
Standard deviation & 0.497462628 & Standard deviation & 0.096225045
\end{tabular}

pretest, the students display serious difficulties in differentiating the historical method from historical thinking, linking both with the concepts of "historical knowledge," "historical content," and "learning about history." In the posttest results, the improvement is significant; more understanding of the historical method is observed, clearly linked to the idea and concept of "research," "scientific method of history," "historical sources," and "stages of historical analysis." In that regard, the following responses are good examples: "it is the method used to make history and it consists of asking an initial question, looking for sources, analyzing them, comparing them, proposing hypotheses, and trying to confirm them."

Slightly different results are observed in the responses to question 6 (Table 5) and its qualitative details in question 7 on knowledge of primary historical sources. For question 6 , most of the sample, both in the pretest and the posttest, showed that they knew this type of source. Despite this, the increase after the TPACK model proposal was significant, which is logical given the central role of the sources in it (from 72 students, 56\%, in the pretest to $107,99 \%$, in the posttest). In any event, a slightly higher prior lack of knowledge than that perceived by the students was evidenced for question 7. In general, they were incapable of giving more than two examples of primary historical sources, which were also generic and mostly written. The most common cited were: "a letter," "a text," and an "article." In contrast, most of the responses to question 7 in the posttest presented more than four different historical sources and their references were also far broader in type and more specific in the description, with examples such as "photograph of Franco," "Greek ceramics," "remains found in an archaeological excavation," and "cave drawings."

Finally, concerning issues focusing on implementing ICTswhich for this proposal were especially specified in questions $8,9,10$, and 11 for TK and TPK, and questions 12 and 13 for TCK - the results were widely positive, from a general point of view, in both the pretest and the posttest. The response in questions with a closed nominal "Yes/No" qualitative response was transformed into " $1 / 2$ " for the numerical analysis. These were questions $8,10,11$, and 12 (Table 6) of the pretest and posttest analysis instrument in which the students were asked about their ICT knowledge (question 8 "ICT Pretest"

TABLE 6 | Pretest/posttest results questions 8, 10, 11, and 12.

\begin{tabular}{|c|c|c|c|c|c|c|c|}
\hline \multicolumn{2}{|c|}{ ICT pretest } & \multicolumn{2}{|c|}{ ICT posttest } & \multicolumn{2}{|c|}{ ICT prim pretest } & \multicolumn{2}{|c|}{ ICT prim posttest } \\
\hline Mean & 1.00787402 & Mean & 1.01851852 & Mean & 1.00787402 & Mean & 1 \\
\hline Typical error & 0.00787402 & Typical error & 0.01303324 & Typical error & 0.00787402 & Typical error & 0 \\
\hline Median & 1 & Median & 1 & Median & 1 & Median & 1 \\
\hline Mode & 1 & Mode & 1 & Mode & 1 & Mode & 1 \\
\hline Standard deviation & 0.08873565 & Standard deviation & 0.13544537 & Standard deviation & 0.08873565 & Standard deviation & 0 \\
\hline \multicolumn{2}{|c|}{ ICT prim hist pretest } & \multicolumn{2}{|c|}{ ICT prim hist posttest } & \multicolumn{2}{|c|}{ ICT tool pretest } & \multicolumn{2}{|c|}{ ICT tool posttest } \\
\hline Mean & 1.00787402 & Mean & 1 & Mean & 1.19685039 & Mean & 1.0833333 \\
\hline Typical error & 0.00787402 & Typical error & 0 & Typical error & 0.03542265 & Typical error & 0.02671919 \\
\hline Median & 1 & Median & 1 & Median & 1 & Median & 1 \\
\hline Mode & 1 & Mode & 1 & Mode & 1 & Mode & 1 \\
\hline Standard deviation & 0.08873565 & Standard deviation & 0 & Standard deviation & 0.39919304 & Standard deviation & 0.27767392 \\
\hline
\end{tabular}


and "ICT Posttest" in Table 6), the possibility of using ICTs in the primary classroom (question 10 "ICT Prim Pretest" and "ICT Prim Posttest" in Table 6), the use of ICTs specifically in the primary classroom for history instruction (question 11 "ICT Prim Hist Pretest" and "ICT Prim Hist Posttest" in Table 6) and about their knowledge of specific ICT tools for history instruction (question 12 "ICT Tool Pretest" and "ICT Tool Posttest" in Table 6) (see Table 6). The results show a widely positive perception toward ICTs among preservice teachers, a fact observed in other analyses (Cózar et al., 2015; Gómez Trigueros, 2016). Most of the sample knew what ICTs are, believed they were useful in the primary classroom in general, and for history instruction in particular, and, furthermore, were aware of ICT tools for use in the classroom. However, this positive self-perception of their own TPK and TCK did not obtain similar results in the openresponse questions associated with the previous ones (question 9 and question 13). Consequently, as occurred for primary historical sources, the responses to the pretest evidenced generic knowledge of ICTs, as the students mentioned resources such as "PowerPoint," "virtual maps," and even confused them with equipment such as "computers," "tablets," and "digital whiteboards." In this regard, the posttest responses to both questions evidenced a positive trend, especially in outlining the tools, as the students were more specific when identifying possible ICT resources to use in history instruction in primary education. Consequently, although generic aspects such as "webpages for creating timelines," "blog," and "videos" were still mentioned, other elements such as "Kahoot," "Edpuzzle," "Popplet," "Google Earth," "Europeana," and "PARES" began to appear in the responses. However, in many cases the concepts were linked to "computer," "projector," "digital whiteboard," and "tablet," highlighting a confusion between ICT resources and ICT equipment.

\section{DISCUSSION}

In recent years, several analyses have explored the integration of ICTs in teaching-learning processes in various contexts and educational stages (Redecker and Punie, 2017; Cabero and Palacios, 2020; Hidalgo Cajo and Gisbert Cervera, 2020; Ortega-Sánchez and Gómez Trigueros, 2020; Rinder, 2020; Romero Tena et al., 2021). The situation caused by COVID19 has not only led to a trend toward accelerating ICT digitalization and integration processes in the classroom, it has also highlighted some deficiencies and gaps in both the educational system and in teacher training. The challenges of integrating ICTs are multiple and depend on numerous factors that vary based on specific educational contexts. Throughout this study, the didactic proposal implementing the TPACK model in the training of students in the degree in primary education in history allows us to observe certain difficulties and limitations, but it also paves the way toward future innovations and research.

In general, as other analyses have pointed out (Redmond and Peled, 2018; Ladrón et al., 2019; Jiménez Sabino and
Cabero Almenara, 2021), the knowledge types (CK, TK, and PK) and their integrations (CTK, CPK, and TPK) increase, albeit heterogeneously, after implementing courses and pedagogical proposals centered on ICTs such as the one this study concerns. This occurs especially when these teaching-learning processes are put forward in particular contexts with proposals applied to specific didactic, technological, and content problems that are simultaneously integrated, which is why the XK of the TPACK model was revised (Mishra, 2019).

Consequently, this study shows how preservice teachers have a broadly positive perception of history, its importance, and of the need to apply and implement it in the primary school classroom. It also evidences that the perception these preservice teachers have of the importance of ICTs and the knowledge they have of them is highly positive, in line with the most recent analyses (Colomer Rubio et al., 2018; CaberoAlmenara and Llorente-Cejudo, 2020; Koh, 2020), which observe a difference with studies of in-service teachers with more years of experience. This aspect allows us to observe a clear, positive trend in the development of knowledge types linked to ICTs (TK, CTK, and TPK), which, besides showing good initial results, widely improved with the implementation of the TPACK model proposal, and were defined, specified, and applied to the particular problems of history instruction in primary education.

However, combined with these positive aspects, this study observes some difficulties and limitations linked with integrating ICTs into teaching-learning processes. Firstly, and especially, there are divergences between the students' self-perception of TK and the limitations in their open responses, with an important part of the sample confusing ICT tools with equipment, and providing generic rather than specific responses for history instruction. Consequently, as observed in other cases (Miguel-Revilla et al., 2020; Romero Tena et al., 2021), this study evidences the difference between "digital native" and "digital expert," which is crucial for understanding the development of DCE in future. After all, current preservice teachers use ICTs every day. This fact makes them "digital natives," leading to positive results in TK, but not to a satisfactory development of this integrated knowledge.

Consequently, the results worsen when implementing TK in a context and analyzing PTK and TCK. The main limitations occur in this last point. Unlike the observations of Miguel-Revilla et al. (2020), and more in line with the results detected by Colomer Rubio et al. (2018), our analysis has detected that the worst results occur in CK. Although these results clearly improve with the TPACK model proposal implemented in this study, the improvement does not occur until the results are satisfactory. The cause of this limitation lies especially in the students being clearly aware of the importance of CK, PK, and TK, although PK and TK predominate over CK, as observed by García-Valcárcel and Martín del Pozo (2016), among others. As this fact occurs in an integrated knowledge model, it not only affects the teachinglearning process of history concerning its $\mathrm{CK}$, but it also hinders the other knowledge types it interacts with in the classroom. 
On the one hand, CTK evidences problems as it does not implement specific technological tools for history instruction and, instead, it is limited to equipment and generic ICT programs and resources. In this respect, the results of the TPACK proposal based on digitized primary sources with preservice teachers are positive, yet insufficient. The lack of CK perceived by the students influences their capacity to implement specific technological proposals. Furthermore, although the results are better than for CTK, they are also negative in PCK. Even though preservice teachers are aware of the need to integrate knowledge-paying special attention to PK (Colomer Rubio et al., 2018)-and their results regarding PK are positive from a general viewpoint, as in other analyses (Hidalgo Cajo and Gisbert Cervera, 2020), the specific application of this knowledge and its combination with didactic approaches in history instruction are problematic. Consequently, although there are high self-evaluations in PK and, especially, in TK, a fact already observed in prior analyses (García-Valcárcel and Martín del Pozo, 2016), gaps in CK have repercussions in all teaching-learning processes, and, at the same time, in the DCE of preservice teachers.

Nevertheless, these limitations and problems linked to negative CK results do not involve the need for a specific development of this knowledge-quite the contrary in fact. Successful results of this TPACK model proposal show us the possibilities of a knowledge integration process to fully develop DCE. Consequently, difficulties concerning one of its knowledge types, namely CK, must be addressed by integrating this knowledge with other types (CTK and PCK), but not in a specific or isolated manner.

\section{CONCLUSION}

The situation caused by COVID-19 has led to a trend toward accelerating ICT digitalization and integration processes in the classroom. However, at the same time it has showed the lack of DCE on preservice teachers. With the goal of developing DCE in the field of social sciences by integrating content, pedagogical, and technological knowledge in cooperative settings using the TPACK model, this study has shown that preservice teachers' self-perception of TK is highly positive (SO1), that implementing integrated knowledge proposals has positive effects (SO2), and

\section{REFERENCES}

Abbitt, J. (2011). Measuring technological pedagogical content knowledge in preservice teacher education: a review of current methods and instruments. J. Res. Technol. Educ. 43, 281-300.

Agustín, R., Liliasari, S., Sinaga, P., and Rochintaniawati, D. (2019). Assessing pre-service science teachers' technological pedagogical content knowledge (TPACK) on kinematics, plant tissue and daily life material. J. Phys. Conf. Ser. $1157,1-5$.

Angeli, C., and Valanides, N. (2009). Epistemological and methodological issues for the conceptualization, development, and assesment of ICT-TPC: advances in technological pedagogical content knowledge (TPCK). Comput. Educ. 52, 154-168. doi: 10.1016/j.compedu.2008.07.006

Atun, H., and Usta, E. (2019). The effects of programming education planned with TPACK framework on learning outcomes. Particip. Educ. Res. 6, 26-36. that despite their limitations, these proposals especially make it possible to develop the most problematic aspects, namely PCK and TCK, which are both disadvantaged by preservice teachers' self-perceived deficiencies concerning CK in history (SO3). Besides, this study shows the fundamental difference between "digital native" and "digital expert," and its influence on the present and future development of DCE.

All these elements evidence that implementing specific didactic proposals based on the TPACK model to develop DCE in preservice teachers opens up a field of analysis that is innovative and beneficial, albeit not without challenges. Moreover, they show the need for a development of knowledge integration process to fully develop DCE, taking into account the different knowledge types (CK, TK and PK) but mostly, their integrations (CTK, CPK, and TPK) in a particular context (XK). Even though research should continue to explore the limitations and problems of implementing certain knowledge types, the integrating proposal is still the path to follow for teaching-learning processes in which ICTs are increasingly the central and essential resource for both teachers and students.

\section{DATA AVAILABILITY STATEMENT}

The raw data supporting the conclusions of this article will be made available by the authors, without undue reservation.

\section{AUTHOR CONTRIBUTIONS}

CC-M and AL contributed to conception and design of the study and wrote sections of the manuscript. CC-M organized the database, performed the statistical analysis, and wrote the first draft of the manuscript. All authors contributed to manuscript revision, read, and approved the submitted version.

\section{FUNDING}

This work was supported by the Grupo de Investigación ARGOS (S50_20R), University of Zaragoza.

Barac, K., Prestridge, S., and Main, K. (2017). Stalled innovation: examining the technological, pedagogical and content knowledge of Australian university educators. Aust. Educ. Comput. 32.

Baran, E., and Uygun, E. (2016). Putting technological pedagogical and content knowledge (TPACK) in action: an integrated TPACK-design-based learning (DBL) approach. Australas. J. Educ. Technol. 32, 47-63.

Britt, M., and Aglinskas, C. (2002). Improving students' ability to identify and use source information. Cogn. Instr. 20, 485-522. doi: 10.1207/s1532690xci2 $004 \_2$

Cabero, J. (2014). La Formación del Profesorado en TIC: Modelo TPACK. Sevilla: Secretariado de Recursos Audiovisuales y Nuevas Tecnologías de la Universidad de Sevilla.

Cabero, J., and Marín, V. (2014). Miradas sobre la formación del profesorado en Tecnologías de Información y Comunicación (TIC). Enl@ace Rev. Venez. Inf. Tecnol. Conocimiento 11, 11-24. 
Cabero, J., Marín, V., and Castaño, C. (2015). Validación de la aplicación del modelo TPACK para la formación del profesorado en TIC. @tic Rev. Innov. Educ. 14, 13-22.

Cabero, J., and Palacios, A. (2020). Marco Europeo de competencia digital docente "DigCompEdu" y cuestionario "DigCompEdu Check-in". EDMETIC Rev. Educ. Mediát. TIC 9, 213-234. doi: 10.21071/edmetic.v9i1.12462

Cabero-Almenara, J., and Llorente-Cejudo, C. (2020). Covid-19; transofmración radical de la digitalización en las instituciones universitarias. Campus Virtuales 9, 25-34.

Cejas León, R., Navío Gámez, A., and Barroso Psuna, J. (2016). Las competencias del profesorado universitario desde el modelo TPACK (Conocimiento Tecnológico y Pedagógico del contenido). Pixel Bit Rev. Medios Educ. 49, 105-119. doi: 10.12795/pixelbit.2016.i49.07

Cochran, K., King, R., and DeRuiter, J. (1993). Pedagogical content knowledge: an integrative model for teacher preparation. J. Teach. Educ. 44, 263-272. doi: $10.1177 / 0022487193044004004$

Colomer Rubio, J., Sáiz Serrano, J., and Bel Martínez, J. (2018). Competencia digital en futuros docentes de ciencias sociales en educación primaria: análisis desde el modelo TPACK. Educ. Siglo XXI 36, 107-128. doi: 10.6018/j/32 4191

Commission of the European Communities (2006). Recommendation of the European Parliament and of the Council (18 December) 2006/962/EC. Brussels: European Commission.

Cózar, R., Zagalaz, J., and Sáez, J. (2015). Creando contenidos curriculares digitales de ciencias sociales para educación primaria. Una experiencia TPACK para futuros docentes. Educ. Siglo XXI 33, 147-168. doi: 10.6018/j/240921

Flores, H., and Rivero, P. (2014). ¿Cómo selecciona el profesorado recursos digitales para enseñar historia? Clío Hist. Hist. Teach. 40, 1-7.

García-Valcárcel M-. R., A., and Martín del Pozo, M. (2016). Análisis de las competencias digitales de los graduados en titulaciones de maestro. RELATEC Rev. Lat. Am. Tecnol. Educ. 15, 155-168.

Gómez Trigueros, I. (2016). La inclusión de las tecnologías en la formación incial del profesorado: una intervención de aula a través del modelo TPACK. Tendenc. Pedagóg. 28, 133-152. doi: 10.15366/tp2016.28.010

Gómez Trigueros, I. M. (2017). La construcción de contenidos curriculares para el trabajo de la escala del mapa con tecnología a través del modelo TPACK. Enseñ. Cienc. Soc. 16, 53-65.

González, N., Ramírez, A., and Salcines, I. (2018). Competencia mediática y necesidad de alfabetización audiovisual de docentes y familias españolas. Educ. XX1 21, 301-321. doi: 10.5944/educxx1.16384

Graham, C., Culatta, R., Pratt, M., and West, R. (2004). Redesigning the teacher educationtechnology course to emphasize integration. Comput. Sch. 21, 127148. doi: 10.1300/J025v21n01_10

Graham, C. R., Burgoyne, N., Cantrell, P., Smith, L., Clair, L. S., and Harris, R. (2009). TPACK development in science teaching: measuring the TPACK confidence of inservice science teachers. TechTrends 53, 70-79.

Hargrave, C., and Hsu, Y. (2000). Survey of instructional technology courses for pre-service teachers. J. Technol. Teach. Educ. 8, 303-314. doi: 10.1016/j.dib. 2019.104875

Haydn, T. (2013). "What does it mean "to be a good at ICT" ass a history teacher?", in Using New Technologies to Enhance Teaching and Learning in History, ed. T. Haydn (London: Routledge), 6-28.

Hidalgo Cajo, B. G., and Gisbert Cervera, M. (2020). Análisis de las competencias digitales del profesorado universitario desde el modelo TPACK (conocimiento tecnológico y pedagógico del contenido). INNOVA Res. J. 5, 79-96.

Hsu, Y.-Y., and Lin, C.-H. (2020). Evaluating the effectiveness of a preservice teacher technology training module incorporating SQD strategies. Int. J. Educ. Technol. High. Educ. 17:31.

International Society for Technology in Education [ISTE] (2008). National Educational Technology Standards for Teachers, 2nd Edn. Washington, DC: International Society for Technology in Education.

Jang, S.-J., and Chen, K.-C. (2010). From PCK to TPACK: developing a transformative model for pre-service science teachers. J. Sci. Educ. Technol. 19, 553-564.

Jiménez Sabino, M. J., and Cabero Almenara, J. (2021). Los conocimientos tecnológicos, pedagógicos y de contenidos del profesorado universitario andaluz sobre las TIC. Análisis desde el modelo TPACK. Innoeduca Int. J. Technol. Educ. Innov. 7, 4-18. doi: 10.24310/innoeduca.2021.v7i1.11940
Kali, Y., Sagy, O., Benichou, O., and Levin, R. (2019). Teaching expertise reconsidered: the technology, pedagogy, content and spaces (TPeCS) knowledge framework. Br. J. Educ. Technol. 50, 2162-2177.

Kaplon-Schilis, A., and Lyublinskaya, I. (2020). Analysis of relationship between five domains of TPACK framework: TK, PK, CK math, CK science, and TPACK of pre-service special education teachers. Technol. Knowl. Learn. 25, 25-43.

Kaplowitz, M., Hadlock, T., and Levine, R. (2004). A comparison of Weand mail survey responde rates. Public Opin. Q. 68, 94-101. doi: 10.1093/poq/nfh006

Koehler, M., and Mishra, P. (2008). "What is technological pedagogical content knowledge (TPCK)?," in Handbook of Technological Pedagogical Content Knowledge (TPCK) for Educators, ed. AACTE Committee on Innovation and Technology (New York, NY: Routledge), 1-30.

Koh, J. H. (2019). TPACK desing scaffolds for supporting teacher pedagogical change. Educ. Technol. Res. Dev. 67, 577-595.

Koh, J. H. (2020). Three approaches for supporting faculty technoligical pedagogical content knowledge (TPACK) creation through instrucional consultation. Br. J. Educ. Technol. 51, 2529-2543.

Kong, S.-C., and Lai, M. (2021). A proposed computational thinking teacher development framework for K-12 guided by the TPACK model. J. Comput. Educ. 8, 1-24.

Ladrón, L., Cabero, J., and Almagro, B. (2019). El conocimiento tecnológico, pedagógico y disciplinar del profesorado de educación física. Retos 36, 362-369.

Lee, E., Brown, M., Luft, J., and Roehrig, G. (2007). Assessing beginning secondary science teachers'PCK: pilot year results. Sch. Sci. Math. 107, 52-60. doi: 10.1111/ j.1949-8594.2007.tb17768.x

Lee, M., and Tsai, C. (2010). Exploring teachers' perceived self efficacy and technological pedagogical content knowledge with respect to educational use of the World Wide Web. Instr. Sci. 38, 1-21. doi: 10.1007/s11251-008-9075-4

Lopera Pérez, M., Arias, V., Jiménez, M., Ospina Pineda, D., and Valderrama Muñoz, A. (2020). Aportes de la revisión de literatura al diseño de una ruta de apropiación TIC, vinculada con el modelo tecnológico-pedagógico-disciplinar. Rev. Virtual Univ. Catól. Norte 62, 276-307. doi: 10.35575/rvucn.n62a11

Miguel-Revilla, D., Martínez-Ferreira, J. M., and Sánchcez-Agustí, M. (2020). Assessing the digital competence of educators in social studies: an analysis in initial teacher training using the TPACK-21 model. Australas. J. Educ. Technol. 36, 1-12.

Ministry of Education Malaysia (2012). Malaysia Education Blueprint 2012-2025. Putrajaya: Ministry of Education Malaysia.

Mishra, P. (2019). Considering contextual knowledge: the TPACK diagram gets an upgrade. J. Digit. Learn. Teach. Educ. 35, 76-78. doi: 10.1080/21532974.2019. 1588611

Mishra, P., and Koehler, M. J. (2006). Technological pedagogical content knowledge: a framework for teacher knowledge. Teach. Coll. Rec. 108, 10171054.

Moersch, C. (2002). Measures of success: six instruments to assess teachers' use of technology. Learn. Lead. Technol. 30, 13-24.

Neuman, W. (2007). Basics of Social Research. Qualitative and Quantitative Approaches. London: Pearson.

Ortega Sánchez, D. (2015). La enseñanza de las ciencias sociales, las TIC y el Tratamiento de la Información y Competencia Digital (TICD) en el grado de maestro/a de educación primaria de las universidades de Castilla y León. Enseñ. Cienc. Soc. Rev. Investig. 14, 121-134.

Ortega-Sánchez, D., and Gómez Trigueros, I. M. (2019). Didactics of historicalcultural hereitage QR codes and the TPACK model: an analytic revision of three classroom experiences in Spanish higher education contexts. Educ. Sci. 9:117. doi: 10.3390/educsci9020117

Ortega-Sánchez, D., and Gómez Trigueros, I. M. (2020). MOOCs and NOOCs in the training of future geography and history teachers: a comparative crosssectional study based on the TPACK model. IEEE Acess 8, 4035-4042. doi: 10.1109/access.2019.2963314

Ortiz-Colón, A. M., Ágreda Montoro, M., and Rodríguez Moreno, J. (2020). Autopercepción del profesorado de Educación Primaria en servicio desde el modelo TPACK. Rev. Electrón. Interuniv. Form. Prof. 23, 53-65. doi: 10.6018/ reifop. 415641

Özgen, K., and Serkan, N. (2020). Intelligent data analysis of interactions and relationships among technological PEdagogical content knowledge constructs via rough set analysis. Contemp. Educ. Technol. 11, 77-98. doi: 10.30935/cet. 646769 
Phillips, M. (2016). Processes of practice and identity shaping teachers' TPACK enactment in a community of practice. Educ. Inf. Technol. 22, 1771-1796. doi: 10.1007/s10639-016-9512-y

Phillips, M., Koehler, M., and Rosenberg, J. (2016). “Considering context: teachers' TPACK development and enactment," in Research Highlights in Technology and Teacher Education, eds L. Liu and D. Gibson (Chesapeake, VA: Society for Information Technology \& Teacher Education), 53-60.

Porras-Hernández, L., and Salinas-Amescua, B. (2013). Strengthening TPACK: a broader notion of context and the use of teacher's narratives to reveal knowledge construction. J. Educ. Comput. Res. 48, 223-244. doi: 10.2190/ec.48.2.f

Price, L., and Kirkwood, A. (2014). Using technology for teaching and learning in higher education: a critical review of the role of evidence in informing practice. High. Educ. Res. Dev. 33, 549-564. doi: 10.1080/07294360.2013.841643

Ramma, Y., Bholoa, A., Watts, M., and Sylvain, P. (2018). Teaching and learning physics using technology; making a case for the affective domain. Educ. Inq. 9, 210-236.

Redecker, C., and Punie, Y. (2017). European Framework for the Digital Competence of Educators: DigCompEdu. Luxembourg: Publications Office of the European Union.

Redmond, P., and Peled, Y. (2018). Exploring TPACK among pre-service teachers in Australia and Israel. Br. J. Educ. Technol. 50, 2040-2054. doi: 10.1111/bjet. 12707

Rinder, J. (2020). Helping Future Teacher do History: The Effectiveness of the National Archives Docsteach Program on the Historical Thinking and Percepcion of History of Preservice Teachers. Ph.D. dissertation. Columbia, SC: University of South Carolina.

Rivero, P., and Mur, L. (2015). Aprender ciencias sociales en la web 2.0. Iber 80, $30-37$.

Romero Tena, R., Llorente Cejudo, C., and Palacios Rodríguez, A. (2021). Competencias digitales docentes desarrolladas por el alumnado del grado en educación infanti: presencialidad vs virtualidad. EDUTEC Rev. Electrón. Tecnol. Educ. 76, 109-125. doi: 10.21556/edutec.2021.76.2071

Rosenberg, J. M., and Koehler, M. J. (2015). Context and technological pedagogical content knowledge (TPACK): a systematic review. J. Res. Technol. Educ. 47, 186-210.

Roussinos, D., and Jimoyiannis, A. (2019). Examining primary education teachers' perceptions of TPACK and the related educational context factors. J. Res. Technol. Educ. 51, 1-21.

Sabriego, M. (2012). "El proceso de investigación (parte 2)," in Metodología de la Investigación Educativa, ed. R. Bisquerra (Madrid: La Muralla), 127-163.

Schmidt, D. A., Baran, E., Thompson, A. D., Mishra, P., Koehler, M. J., and Shin, T. S. (2009). Technological pedagogical content knowledge (TPACK). The development and validation of an assessment instrument for preservice teachers. J. Res. Technol. Educ. 42, 123-149.

Sevillano, M. (2002). Nuevas Tecnologías, Medios de Comunicación y Educación. Formación Inicial y Permanente del Profesorado. Madrid: Edutorial CCS.

Sharp, L. (2014). Literacy in the digital age. Lang. Lit. Spectr. 24, 74-85.

Shulman, L. (1986). Those who understand: knowledge growth in teaching. Educ. Teach. 15, 4-14.
Shulman, L. S. (1987). Knowledge and teaching: foundations of the new reform. Harv. Educ. Rev. 57, 1-22.

Swallow, M. J., and Olofson, M. W. (2017). Contextual understandings in the TPACK framework. J. Res. Technol. Educ. 49, 228-244.

Tirado, R., and Aguaded, J. (2014). Influlencias de las creencias del profesorado sobre el uso de la tecnología en el aula. Rev. Educ. 363, 230-255.

UNESCO (2008). La Educación Inclusiva: el Camino Hacia el Futuro. Ginebra: UNESCO.

UNESCO (2016). O. d. (20 de 08 de 2016). Ginebra: UNESCO.

Valtonen, T., Sointu, E., Kukkonen, J., Mäkitalo, K., Häkkinen, P., Järvela, S., et al. (2019). Examining pre-service teachers' technological pedagogical content knowledge as evolving knowledge domains: alongitudinal approach. J. Comput. Assist. Learn. 35, 491-502.

Van Driel, J., Verloop, N., and De Vos, W. (1998). Developing science teachers' pedagogical content knowledge. J. Res. Sci. Teach. 35, 673-695.

VanSledright, B. (2013). Assessing Historical Thinking and Understanding: Innovative Designs for New Standards. New York, NY: Routledge.

Van Vaerenewyck, L. M., Harlow Shinas, V., and Steckel, B. (2017). Sarah's story: onte teacher's enactment of TPACK+ in a history classroom. Lit. Res. Instr. 56, 1-18. doi: 10.4018/978-1-60960-750-0.ch001

Voithfer, R., Nelson, M., Han, G., and Caines, A. (2019). Factors that influence TPACK adoption by teacher educators in the US. Educ. Teachnol. Res. Dev. 67, 1427-1453.

Watulak, S., and Kinzer, C. (2013). "Beyond technology skills: toward a framework for critical digital literacies in pre-service technology education," in Critical Digital Literacies as Social Prais: Intersections and Challenges, eds J. Avila and J. Pandya (New York, NY: Peter Lang), 127-153.

Wellington, J. (2015). Educational Research: Contemporary Issues and Practical Approaches. London: Bloomsbury.

Willermark, S. (2018). Technological pedagogical and content knowledge: a review of empirical studies published from 2011 to 2016. J. Educ. Comput. Res. 56, 315-343. doi: 10.1177/0735633117713114

Conflict of Interest: The authors declare that the research was conducted in the absence of any commercial or financial relationships that could be construed as a potential conflict of interest.

Publisher's Note: All claims expressed in this article are solely those of the authors and do not necessarily represent those of their affiliated organizations, or those of the publisher, the editors and the reviewers. Any product that may be evaluated in this article, or claim that may be made by its manufacturer, is not guaranteed or endorsed by the publisher.

Copyright (๑) 2022 Ciriza-Mendivil, Lacambra and Hernández de la Cruz. This is an open-access article distributed under the terms of the Creative Commons Attribution License (CC BY). The use, distribution or reproduction in other forums is permitted, provided the original author(s) and the copyright owner(s) are credited and that the original publication in this journal is cited, in accordance with accepted academic practice. No use, distribution or reproduction is permitted which does not comply with these terms. 